\title{
The impact of explosive weapons on urban services: direct and reverberating effects across space and time
}

Mark Zeitoun, Founder of the UEA Water Security Research Centre, and Professor at the School of International Development, University of East Anglia. Former water and sanitation engineer.

Michael Talhami, ICRC Regional Water and Habitat Advisor (Near and Middle East). Formerly a senior policy advisor addressing the management and governance of water resources problems in conflict settings.

\begin{abstract}
This article reviews the factors that determine the impact of explosive weapons on urban services in space and time, with a focus on drinking water services. The evidence comes from published and unpublished research and records, as well as experience restoring or maintaining such services. Urban services are seen as interconnected, and each composed of interdependent components of people, consumables, and hardware. Elements that make up the components are labelled 'upstream', 'midstream', and 'downstream', to reflect their location and hierarchy in the production and delivery of any urban service. The impact of explosive weapons is broken into the direct effects on any of the components of a service, and the reverberating effects on up and or downstream components of the same service, or on other services. The effects are most commonly observed in service infrastructure, and determined chiefly by the extent of the damage to the functionality of any component. The spatial extent of the impact is found to be determined primarily by the hierarchy of the component suffering the direct impact, with attacks on upstream components being the furthest reaching. The duration of the impact is determined primarily by the pre-explosion 'baseline resilience' of the service, itself a function of system redundancies and emergency preparedness and response. The analysis suggests that the impact is more reasonably foreseeable than may commonly be thought, in the sense that the direct effects of explosives is well-known and that the most important infrastructure is generally identifiable. It follows that proportionality assessments that involve urban services would benefit from: i) the direct and consistent engagement of specialised engineers within the targeting cell; and ii) greater familiarity of the weapons controller with services, infrastructure and systems in urban areas
\end{abstract}


Keywords: Urban services, reverberating effects, explosive weapons, reasonably foreseeable, water and conflict, water and war, critical infrastructure, service system.

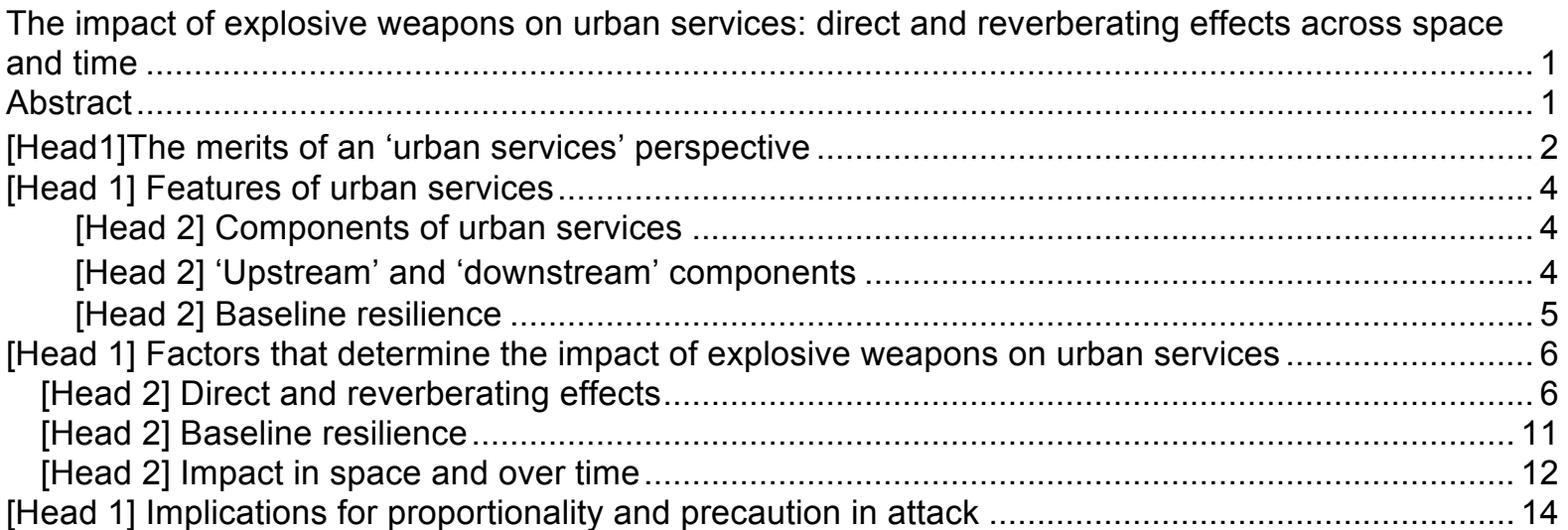

\section{[Head1]The merits of an 'urban services' perspective}

Contention about the use of explosive weapons in populated areas is usually centred on law and ethics, rather than infrastructure, and the basis for the expanded or constricted use of explosive weapons tends to be laid more by lawyers, social scientists, and military planners than by engineers. Yet, as this analysis of the factors that determine the spatial and temporal impact of explosive weapons on urban services shows, a grounded technical awareness adds considerable substance to the discussions and debate surrounding this issue.

The analysis builds upon the growing body of research that explores the impact of explosive weapons upon people and structures, notably the work circumscribing the legal parameters for the use of explosive weapons in populated areas, 'forensic architecture'-type studies, ${ }^{2}$ epidemiological studies, ${ }^{3}$ operational resilience and systems thinking, ${ }^{4}$ and disaster risk reduction. ${ }^{5}$

1 See Brehm M, Borrie J. Explosive Weapons: Framing the Problem. UN Institute for Disarmament Research: Geneva, Background Paper No 1 of the Discourse on Explosive Weapons project, 2010; Gisel L, in Greppi E, with Beruto GL, eds. The use of explosive weapons in densely populated areas and the prohibition of indiscriminate attacks. 37th Round Table on Current Issues of International Humanitarian Law; 2015; Sanremo 4-6 September 2014. International Institute of Humanitarian Law; Robinson I, Nohle E. "Proportionality and precautions in attack: the reverberating effects of using explosive weapons in populated areas". International Review of the Red Cross; in press in press.

2 See HRW. Precisely Wrong: Gaza Civilians Killed by Israeli Drone-Launched Missiles. New York: Human Rights Watch, 2009; HRW. Off Target: The Conduct of the War and Civilian Casualties in Iraq. New York: Human Rights Watch, 2003; Weizman E. The Least of All Possible Evils. London: Verso, 2011; AOAV. Explosive Events: Monitoring explosive violence in 2013. Action on Armed Violence: London, 2013. For deeper discussion, refer to the interview with Weizman (this volume).

3 E.g. Guha-Sapir D, Rodriguez-Llanes JM, Hicks MH, et al. "Civilian deaths from weapons used in the Syrian conflict". BMJ; 2015 2015, h4736; Guha-Sapir D, van Panhuis WG. Armed Conflict and Public Health: A report on knowledge and knowledge gaps. WHO Collaboraing Centre for Research on the Epidemiology of Disasters, Catholic University of Louvain: Brussels, 2002; Rappert B, Moyes R, Lang I. "The case for addressing explosive weapons: Conflict, violence and health". Social Science \& Medicine; 2012 2012, 2047 - 54. 
The investigation is not limited to the use of explosive weapons "with wide-area effects", as it queries the nature and extent of their impact on urban services in space and over time. With a focus on drinking water services, that impact is understood in terms of direct effects and reverberating effects. Though explosive weapons may impact any of the components necessary for the functioning of a service (i.e. people, consumables, or hardware), it is most commonly observed in service infrastructure, and determined chiefly by the extent of the damage to the functionality of any component. The analysis finds that the spatial extent of the impact on urban services is found to be determined chiefly by the position of the damaged component within the hierarchy of the service, with attacks on socalled upstream components (i.e. those that produce the action or commodity that the service provides) typically having the most widespread impact. The duration of the impact is determined primarily by the 'baseline resilience' of the service prior to the explosion, which is a function of the nature of system redundancies and capacity for emergency preparedness and response. These findings feed directly into the debates about the implications for the rules on proportionality and precaution in attack, ${ }^{6}$ by shedding light on what impact on urban services can be considered 'reasonably' foreseeable.

\section{[Head 2]Methodology}

The analysis is based on public and confidential records, and experience restoring or maintaining service provision. In particularl, the research draws on the prolonged experience of the ICRC in providing support to municipal service providers and utilities in Gaza, Iraq and Syria. The analysis also builds directly on the ICRC's Urban Services During Protracted Armed Conflict report, as well as discussions stimulated by the authors at the ICRC Expert Meeting on EWPA, ${ }^{7}$ the 16th Bruges Colloquium on $I H L,{ }^{8}$ and the $32^{\text {nd }}$ International Conference of the Red Cross and the Red Crescent side event on EWPA. ${ }^{9}$

4 Hay AH. Operational Survival: Putting Resilience at the Core of Infrastructure Planning. Explora Research: 2013..

5 FEMA. Reference Manual to Mitigate Potential Terrorist Attacks Against Buildings. US Department of Homeland Security / FEMA 426: Washington DC, Risk Management Series, 2003. + Wathab Q\&A [this volume]

6 Robinson I, Nohle E. "Proportionality and precautions in attack: the reverberating effects of using explosive weapons in populated areas". International Review of the Red Cross; in press in press; Gisel L, in Greppi E, with Beruto GL, eds. The use of explosive weapons in densely populated areas and the prohibition of indiscriminate attacks. 37th Round Table on Current Issues of International Humanitarian Law; 2015; Sanremo 4-6 September 2014. International Institute of Humanitarian Law.

7 February 2015 - see ICRC (2015). Expert Meeting Explosive Weapons in Populated Areas: Humanitarian, Legal, Technical Aspects Chavannes-de-Bogis, Switzerland 24-25 February 2015, International Committee of the Red Cross.

8 November 2015 - see ICRC (2016). Urban Warfare - Proceedings of the Bruges Colloquium. 16th Bruges Colloquium, 15-16 October 2015, Bruges, International Committee of the Red Cross.

9 ICRC (2015). The use of explosive weapons in populated areas and the need to better protect civilians. Side event held in Geneva, 9 December 2015, International Committee of the Red Cross. 


\section{[Head 1] Features of urban services}

This section lays the technical foundation of urban services required to assess the factors that determine the impact that explosive weapons have upon them.

\section{[Head 2] Components of urban services}

The term 'service' is used here to mean the provision of commodities, actions or other items of value to an urban population - and could include electricity, health, water, wastewater collection and treatment, and solid waste disposal. ${ }^{10}$ Urban services are increasingly complex systems, and the general public's limited knowledge of their internal workings is contrasted by their near total-dependence upon them.

Most urban services are dependent upon each other. For example, a damaged electrical transformer can cut the power to a water booster pumping station, and so disrupt the water supply to an entire neighborhood and/or to the local hospital. Furthermore, each urban service requires three components in order to function: people (e.g. service provider staff, private sector contractors and entrepreneurs), consumables (e.g. fuel, chlorine, medicines), and hardware (e.g. equipment, heavy machinery, infrastructure). The bulk of the focus of this article is on the infrastructure element of the hardware component in relation to its function and position within the broader system of any given service.

Each component of a service affects the other. For example, even with wellmaintained water infrastructure, experienced water utility staff cannot provide water to consumers if there is no power to run the booster pumps that maintain the pressure in the distribution network.

\section{[Head 2] 'Upstream' and 'downstream' components}

There is a hierarchy of importance within the components of a service, as some elements of each component are more important for the effective functioning of the service, particularly for infrastructure. Infrastructure that is disabled at the supply-end of an infrastructure system is more disruptive to more people than are elements of infrastructure that deliver the product half-way down the line, or to the end-user, for example. At the top of this hierarchy is what are referred to here as 'upstream' components, as shown in Figure 1. 'Upstream' components produce the items of value that the service delivers (typically a commodity or an action), such as water treatment plants, wastewater treatment plants, or electrical power plants. 'Midstream' components are those that are necessary for the storage or delivery (but not production) of the bulk of the commodity, action, or other items of value, such as water reservoirs and booster pumping stations, or an on-grid electrical sub-station and transmission lines. 'Downstream' components of any service are those that ensure the storage or delivery to the end-users of the service, such as a water distribution network or an electrical transformer. The significance of the distinction is related to scale; upstream components of a

\footnotetext{
10 The list of other "basic services," such as radio and television, ports, banking, education, roads and telecommunications, is potentially non-exhaustive. It is likely to change with each context.
} 
service (read elements of infrastructure) provide for the largest coverage area and hence the greatest number of people served, while downstream components provide for a smaller coverage area and hence fewer people served.

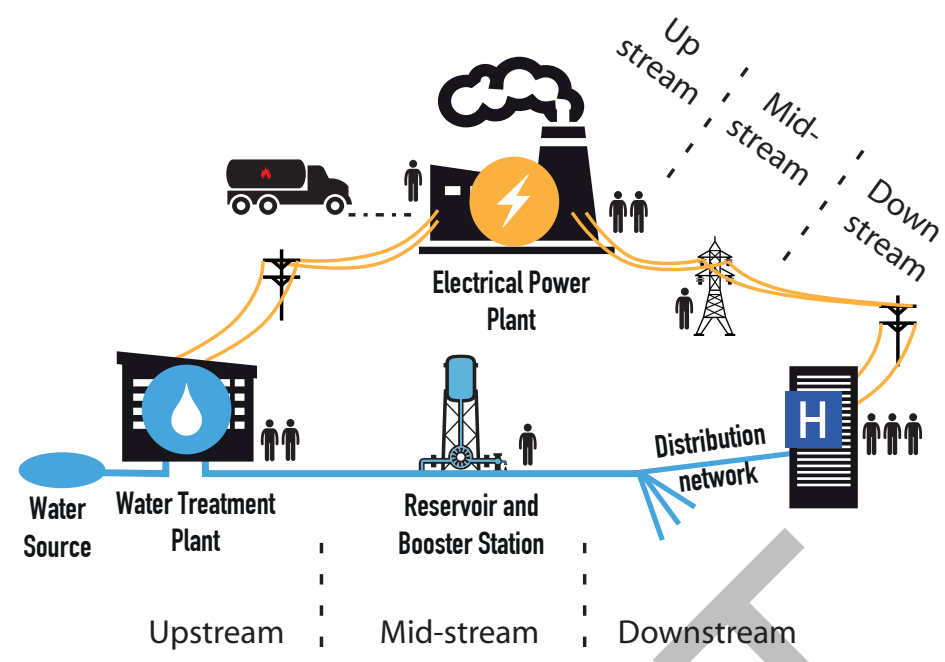

Figure 1. Sketch showing the hiearchy of components within water and electricity services.

The hierarchy of importance of components also holds true for the people and consumable components of a service, if to a lesser degree. For a drinking water service, socalled 'upstream' people include the key operations personnel required for a service to run, while maintenance, planning, and administrative staff can be considered key 'midstream' people, and consumers 'downstream'. In terms of consumables, fuel to run the water treatment plant is considered 'upstream', while treatment chemicals (such as chlorine for dosing at booster pumping stations) are a 'midstream' consumable, and fuel or chlorine tablets for household treatment are 'downstream' consumables.

\section{[Head 2] Baseline resilience}

It matters also what condition a service is in prior to an attack, as existing underlying vulnerabilities in some cases can be greatly exacerbated. An impoverished and poorly governed service provider (Basrah in 2004, say) can be expected to have fewer options than a well-governed and financially-secure one (e.g. Geneva in 2016), in short because the latter is more resilient.

'Service resilience' ${ }^{11}$ may be measured in terms of redundancies (meaning replication of elements of infrastructure, substitute staff), and level of preparedness or ability to respond (e.g. the number of qualified staff, volume of prepositioned stocks of consumables, quality of infrastructure). ${ }^{12}$ Of the two, the ability to respond may be the more important measure, as it

\footnotetext{
11 'Service resilience' is used here in a way that is analogous to 'operational resilience', which is defined as "that essential ability of an operation to respond to and absorb the effects of shocks and stresses and to recover as rapidly as possible normal capacity and efficiency" Hay AH. After the Flood: Exploring Operational Resilience. Victoria: FriesenPress, 2016.

12 Dross P, Talhami M, de Pinha-Oliveira E, et al. "Urban Services in Protracted Armed Conflict". Crisis Response Journal; 2016 (3) 2016. See also interview with WatHab (this volume).
} 
captures the combined ability to make the best use of built-in redundancies, while ensuring that viable alternatives act as a capability for restoring a service. To return to the previous example, Geneva's current drinking water service is considered more resilient than that of Basrah in 2004, in both qualitative and quantitative terms. Each has redundancies designed and built into them (and the service of Basrah may have more built-in, whilst coping with the effect of armed conflict and sanctions) ${ }^{13}$ but the former is likely to have a greater number and more reliable supply of stocks, well operated and maintained infrastructure, and systems to support the personnel responsible to implement emergency preparedness plans.

\section{[Head 1] Factors that determine the impact of explosive weapons on urban services}

This section establishes the factors that determine the extent of the impact of the use of explosive weapons on urban services in space and over time. 'Explosive weapons' is understood here to mean weapons that use high explosives to project a blast wave, fragmentation, or thermal energy from a point of detonation. ${ }^{14}$ Types of explosive weapons include artillery shells, missiles, rockets, and improvised explosive devices.

\section{[Head 2] Direct and reverberating effects}

The ICRC's 2015 Urban Services report stressed how the direct and indirect impact of protracted armed conflict and trade sanctions accumulate over time. Such impact accumulates as repeated bouts of violence within the protracted conflict degrade the service (whether its people, hardware, or consumables) to a point where its restoration is no longer economically feasible under the prevailing conditions, if possible at all. This section adapts the approach to examine in particular the impact of explosive weapons on urban services, with 'impact' understood in terms of both direct and reverberating effects.

As shown in Figure 2, the impact of the detonation of explosive weapons on urban services is gauged in terms of direct and reverberating effects. Direct effects of explosive weapons on urban services refers here to the immediate and physical impact caused by the explosion. Examples include the death or injury of operations and maintenance crews, damage to a water reservoir, or to a warehouse of spare parts and consumables. The direct effect of the explosion can have consequences on other components of the same service when they are interdependent. Reverberating effects of explosive weapons on urban services refers to such consequences, and are discussed further following.

\footnotetext{
${ }^{13}$ Ibid.

14 Borrowing from Brehm M, Borrie J. Explosive Weapons: Framing the Problem. UN Institute for Disarmament Research: Geneva, Background Paper No 1 of the Discourse on Explosive Weapons project, 2010. and AOAV. Explosive Events: Monitoring explosive violence in 2013. Action on Armed Violence: London, 2013.
} 
Explosion $\longrightarrow$ Direct effects... $\quad+$ Reverberating effects...

... on people, hardware, $\quad$... on up, mid, or downstream and consumables. components of the same service;

... on other services (the 'domino effect');

... far from the impact zone; and

... long after the detonation has occured.

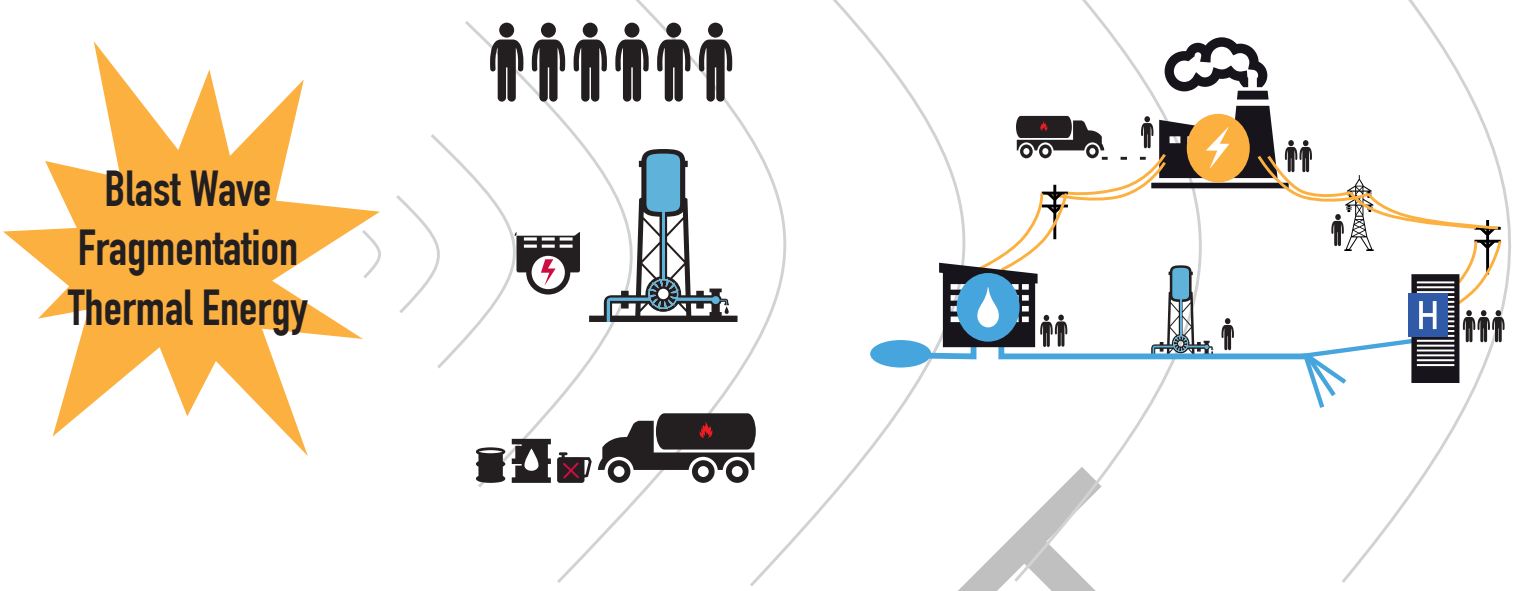

Figure 2. Depiction of the direct and reverberating effects of the detonation of an explosive weapon on the components of an urban service.

The consequences of explosive weapons can feed into the vicious cycles and other dynamics (e.g. trade sanctions, brain drain) of the indirect and cumulative impact of protracted armed conflict upon urban services, ${ }^{1}$ whether these be on the whole system of the same service, or on other services. An increased spread of communicable disease due to disrupted water supply is just one example, ${ }^{15}$ though this is possible even in more acute conflicts. More immediate and generally less enduring than that example are the reverberating effects on the urban services themselves. While the consequences of the use of explosive weapons in general "are not limited to death, physical injury and disability, but also include long-term impacts on mental well-being", ${ }^{16}$ the reverberating effects of explosive weapons on urban services are relatively bounded in space and over time. More specifically, the reverberating effects of explosive weapons on urban services are limited by the extent of the damage to upstream and midstream infrastructure, by the spatial distribution of the reverberations, and by the time required to restore the service. ${ }^{17}$

\footnotetext{
${ }^{15}$ Hunter, Paul R., Denis Zmirou-Navier and Philippe Hartemann (2009). Estimating the impact on health of poor reliability of drinking water interventions in developing countries. Science of the Total Environment 407: 2621 - 2624; Hunter, Paul R., Alan M. MacDonald and Rlchard C. Carter (2010). Water Supply and Health. PLOS ONE 7(11).

${ }^{16}$ ICRC. Explosive Weapons in Populated Areas. International Committee of the Red Cross: Geneva, Factsheet February 2016, 2016.

${ }^{17}$ What are referred to here as reverberating effects of explosive weapons on urban services are a subset of - the 'foreseeable reverberating effects of an attack' in the general sense discussed in Robinson and Nohle (this volume) which are "otherwise known as "knock-on effects", "indirect effects" or "long-term consequences". Reverberating effects on infrastructure are similar to what Patterson (2000) calls 'first order ripple effects' in her discussion on the impact of urban infrastructure disruptions on military operations and non-combatants. Patterson CM. Lights Out
} 
The reverberating effects of explosive weapons on urban services also vary with each particular component of a service. The reverberating effects on an infrastructure system ${ }^{18}$ can be seen upstream, as when damage to a public water reservoir renders the transmission line and water treatment plant upstream useless, or downstream, as when damage to a domestic water reservoir eliminates the storage capacity and hence the supply of water to an entire neighbourhood. The maximum theoretical spatial extent of the reverberating effects is thus limited to the breadth of the service area, for example the physical footprint of the service infrastructure. ${ }^{19}$ The duration of the reverberating effects varies. For example, the buffer and storage function of a 'downstream' water reservoir (that is, one that serves an entire neighbourhood) can in some cases be restored to a limited degree by the installation within hours or days of temporary water tanks, or it can be repaired to full functionality within weeks. $^{20}$ In other cases, for example when the water reservoir cannot be repaired and its storage function cannot be bandaged with 'quick-fixes', the continuity of the supply and pressure in the line is interrupted, leading to undue stress on distribution pipes further downstream, resulting in a less reliable service for the end user. And the restoration of a booster pumping station can take several months or even over a year, particularly if the pumps and electrical panels need to be imported. ${ }^{21}$

The people and consumables so important to the effective functioning of an urban service also suffer from explosive weapons, of course. Whether an explosive weapon should completely destroy the sole warehouse of spare parts and consumables, or kill or maim a large number of the municipal staff, the spatial extent and duration of the reverberating effects would likely be similar to those observed in infrastructure. Cases where the effects of the use of explosive weapons will reverberate 'upstream or 'downstream' on people or consumables are relatively few, however, and the consequences are generally more contained both in space and over time. For instance, if a warehouse full of spare parts has been destroyed, the reverberating effects on the system will be felt in space at the related infrastructural points that have broken-down or failed, whereas the impact over time is a function of the time required to procure and install the replacement parts (as well as the replacement spare parts required to retain the pre-explosion level of preparedness).

and Gridlock: The Impact of Urban Infrastructure Disruptions on Military Operations and NonCombatants. Institute for Defense Analyses: Alexandria, VA, No IDA/HQ-D-2511, 2000..

${ }^{18}$ By 'infrastructure system', we mean the network of elements that make up all of the infrastructure required within a system to deliver the service (bearing in mind that 'infrastructure' is just one element of the 'hardware' component of a service).

${ }^{19}$ This could extend to peri-urban areas that are supplied through water tankers filling from a point on the main transmission line.

20 Nembrini PG, Generelli C, Al-Attar A, et al. Basrah water supply during the war on Iraq. International Committee of the Red Cross: 2003. See also OSCE. Access to water in conflictaffected areas of Donetsk and Luhansk regions. Organisation for Security and Co-operation in Europe - Special Monitoring Mission to Ukraine: 2015.

${ }^{21}$ Magnaldi S, Patera J. Kaboul, de la destruction à la reconstruction. In: Grünewald F, Levron E, eds. Villes en guerre et guerres en villes. Paris: Editions Karthala, 2004; ibid.; Grünewald F, editor. Working in Syrian cities at war: humanitarian aid under constraints: Les dossiers to Grotius International (online 31 October 2013), 2013; Grünewald F, Levron E, editors. Villes en guerre et guerres en villes. Paris: Editions Karthala, 2004. 
Furthermore, the damage caused by explosive weapons on any component of a service can have a "domino effect" on other services. ${ }^{22}$ Damage to an electrical sub-station can halt the municipal drinking water supply, and this 'toppling' type of reverberating effect can lead to loss of sterilisation capacity in the operating theatre, ${ }^{23}$ as just one example.

The potential reverberating effects of explosive weapons on infrastructure at different levels of hierarchy of service components is presented in Table 1. Consider as a hypothetical example the reverberating effects of a direct strike on an 'upstream' water treatment plant that damages three of six of the main transmission pumps. If the plant was normally operated with four pumps with the two remaining reserved for scheduled switchover, the maximum volume of water that could be supplied to residents after the attack would be three quarters of the normal amount. Depending on the configuration of the drinking water distribution network (i.e. whether closed-loop (meaning a more effective circulation of water), or openended (which has much more vulnerable sections)), this could result in one quarter of the users near the end of the distribution network receiving less water than normal, as well as silting in the unused distribution (and possibly also transmission) pipelines. There would also be the reverberating effect of an undue amount of wear on those pumps that still function. These pumps would be likely to fail earlier than they normally would have, thus threatening the entire drinking water service. Similar cases have been documented for Beirut, ${ }^{24}$ Baghdad, ${ }^{25}$ Grozny, ${ }^{26}$ Huambo, ${ }^{27}$ Kabul, ${ }^{28}$ Jenin, ${ }^{29}$ Gaza, ${ }^{30}$ southern Lebanon, ${ }^{31}$ and other places.

In this example, the cumulative impact of the partial damage to the pumps is an entire breakdown of the drinking water service, the result of direct and reverberating effects, and likely to have a domino effect on other services (e.g. health). The extent to which such impact

${ }^{22}$ ICRC. Explosive Weapons in Populated Areas: Humanitarian, Legal, Technical, and Military Aspects. International Committee of the Red Cross: Geneva, Report of the ICRC Expert Meeting in Chavannes-de-Bogis, Switzerland, 24 to 25 February 2015, 2015.. The 'domino effect' may be analogous to what Scmitte and Widmar refer to as a 'knock-on' effect Schmitt M, Widmar E. "On Target: Precision and Balance in Contemporary Law of Targeting". Journal of National Security Law and Policy; 2014 (3) 2014.

${ }^{23}$ Giannou C, Baldan M. War Surgery: Working with Limited Resources in Armed Conflict and Other Situations of Violence - Volume 1. International Committee of the Red Cross: Geneva, 2009.

${ }^{24}$ Nembrini PG. Lebanon: Water supply problems during the 1989 and 1990 wars. In: ICRC, ed. Water and War: Symposium on Water in Armed Conflict, Montreux, 21-23 November 1994. Geneva: International Committee of the Red Cross, 1994.

${ }^{25}$ Etienne Y, Nembrini PG. "Establishing water and sanitation programmes in conflict situations: The case of Iraq during the Gulf War". International Journal of Public Health; 1995 (1) 1995, 18 - 26.

${ }^{26}$ Hodgson R, Oppliger A. After the battle of Grozny. In: ICRC, ed. Forum: War and Water, 1999.

${ }^{27}$ Nembrini PG. Huambo (Angola): Water supply in a war torn town - evolution and impact of the different interventions since 1985. Geneva Foundation: Geneva, Cities in War: Thirsty Cities Occasional Paper No 3, 2001.

${ }^{28}$ Pinera J-F. Cities, Water and War: Looking at how water utilities and aid agencies collaborate in cities affected by armed conflicts. Loughborough: LAP LAMBERT Academic Publishing 2011.

${ }^{29}$ Zeitoun M. Conflict and Water in Palestine - The Consequences of Armed Conflict on DrinkingWater Systems in Jenin, West Bank. In: Khatib I, Assaf K, Clayes D, et al., eds. Water Values and Rights. Ramallah, Palestine: Palestine Academy Press, 2005.

${ }^{30}$ Nembrini PG, Moreau A. The Gaza strip: The last "ghetto": an organized deprivation and a denied urban development, 2009.

31 Zeitoun M, Eid-Sabbagh K, Loveless J. "The analytical framework of water and armed conflict: a focus on the 2006 Summer War between Israel and Lebanon". Disasters; 2014 (1) 2014, 22-44. 
will be considered reasonably foreseeable is a function of a number of factors that will be discussed later.

\begin{tabular}{|c|c|c|c|}
\hline & $\begin{array}{l}\text { Upstream components } \\
\text { (e.g. water treatment or } \\
\text { electrical power plants) }\end{array}$ & $\begin{array}{l}\text { Midstream components } \\
\text { (e.g. water reservoirs, booster } \\
\text { pumping stations, or } \\
\text { transmission lines or on-grid } \\
\text { sub-stations) }\end{array}$ & $\begin{array}{c}\text { Downstream } \\
\text { components (e.g. } \\
\text { distribution network or } \\
\text { distribution transformer ) }\end{array}$ \\
\hline $\begin{array}{l}\text { Relative } \\
\text { magnitude of } \\
\text { expected impact }\end{array}$ & High & Medium & Low \\
\hline Direct effects & $\begin{array}{l}\text { Destruction or damage of a } \\
\text { water treatment plant. }\end{array}$ & $\begin{array}{l}\text { Destruction or damage of a } \\
\text { water reservoir serving } \\
\text { multiple neighbourhoods or a } \\
\text { district within a city. }\end{array}$ & $\begin{array}{l}\text { Destruction or damage of a } \\
\text { residential distribution } \\
\text { network, or of a household } \\
\text { connection to the network. }\end{array}$ \\
\hline $\begin{array}{l}\text { Potential } \\
\text { reverberating } \\
\text { effects }\end{array}$ & $\begin{array}{l}\text { Disruption of treatment of } \\
\text { unprocessed water; } \\
\text { disruption in the } \\
\text { transmission of treated water } \\
\text { and the local distribution to } \\
\text { the end user. }\end{array}$ & $\begin{array}{l}\text { Disruption of the pattern of } \\
\text { water supply (i.e. continuity of } \\
\text { supply (reliability), pumping } \\
\text { hours, quantity of water, and } \\
\text { pressure) to a neighbourhood } \\
\text { or neighbourhoods. Upstream, } \\
\text { silting of transmission line; } \\
\text { downstream, silting of } \\
\text { distribution network, } \\
\text { contamination of hospital } \\
\text { water reservoir and or } \\
\text { inadequate supply. }\end{array}$ & $\begin{array}{l}\text { Disruption of the pattern of } \\
\text { water supply (i.e. continuity } \\
\text { of supply (reliability), } \\
\text { pumping hours, quantity of } \\
\text { water, and pressure) to } \\
\text { individual buildings (e.g. } \\
\text { house, block of flats, } \\
\text { factory). }\end{array}$ \\
\hline $\begin{array}{l}\text { Consequences } \\
\text { on the drinking } \\
\text { water } \\
\text { infrastructure } \\
\text { system }\end{array}$ & $\begin{array}{l}\text { Lower volume and quality of } \\
\text { water supplied to the entire } \\
\text { service area (typically city } \\
\text { wide or several } \\
\text { neighbourhoods). }\end{array}$ & $\begin{array}{l}\text { Halted or very poor quality of } \\
\text { water supplied to the } \\
\text { neighbourhood. } \\
\text { continuity in supply. }\end{array}$ & $\begin{array}{l}\text { Halted or very poor quality } \\
\text { of water supplied to affected } \\
\text { households. }\end{array}$ \\
\hline $\begin{array}{l}\text { Physical extent } \\
\text { of direct and } \\
\text { reverberating } \\
\text { effects }\end{array}$ & $\begin{array}{l}\text { Open to entire extent of } \\
\text { service (potentially } \\
\text { confineable in resilient } \\
\text { systems with alternative } \\
\text { production options). }\end{array}$ & $\begin{array}{l}\text { Open to affected portion of } \\
\text { service. }\end{array}$ & $\begin{array}{l}\text { Confined to the localized } \\
\text { service area or household } \\
\text { level. }\end{array}$ \\
\hline $\begin{array}{l}\text { Duration of } \\
\text { direct and } \\
\text { reverberating } \\
\text { effects }\end{array}$ & $\begin{array}{l}\text { (seconds to months } t \\
\text { infrastructure damag }\end{array}$ & $\begin{array}{l}\text { ediate, Short, Medium, or Long- } \\
\text { ars, depending on the extent of } t \\
\text { up, mid, or downsteam, and ba }\end{array}$ & $\begin{array}{l}\text { erm } \\
\text { he damage, whether the } \\
\text { eline service resilience. }\end{array}$ \\
\hline
\end{tabular}

Table 1. Examples of the direct effects, reverberating effects and consequences of explosive weapons on up, mid, and downstream elements of a drinking water infrastructure system, and indication of their magnitude in space and in time.

Consideration of the reverberating effects of a strike affecting a downstream component of a service demonstrates the importance of incorporating the hierarchy of components of any service into the analysis. Particularly when alternative water supplies are of poor quality or risky to access, the ('downstream') household connection to the network is a crucial component for the dignity of life and health of all of its members. The consequences for a family when their connection is damaged by an explosion can be devastating, in terms of dignity, public health or displacement. From a services perspective, however, the damage 
is of relatively less consequence than the disabling of a domestic water reservoir, or other midstream or upstream components. ${ }^{32}$

\section{[Head 2] Baseline resilience}

The deaths of hundreds of doctors in Iraq and Syria ${ }^{33}$ have demonstrated how the direct effect of explosive weapons on the people that a service depends on can have reverberating effects (on that service). In situations of protracted conflict, the direct effect of explosive weapons can be expected to reverberate more pervasively than in conflicts of short duration, because of their eventual contribution to cumulative impact induced overtime by the repeated interplay of direct and indirect impact. A singular attack on any part of a service in a city that has no ongoing armed conflict (say, Geneva, again) is not likely to induce the same extent of brain drain as would repeated attacks in a city living through protracted conflict (as currently seen in Aleppo, for example), because the ability to adapt of those involved has not been repeatedly tested. ${ }^{34}$

The example demonstrates how the reverberating effects of explosive weapons on urban services can be dampened or amplified by the resilience of the service prior to the explosion - what is referred to here as baseline service resilience. From a perspective of the rules of proportionality and precaution in attack, this baseline service resilience would form part of what Robinson and Nohle call the "contextual factors". 35

As previously discussed, the service resilience may be measured in terms of redundancies and the level of emergency preparedness and ability to respond. A drinking water system that has diversified water sources (or multiple water reservoirs that are predesigned for operational flexibility to the same service areas within an urban area) is resilient because each replication sub-divides the service, and so limits the physical extent of and number of people affected by any damage. ${ }^{36}$ The sub-divisions also allow for quicker repair work, as parts of transmission and distribution networks can be isolated without disrupting the entire service area. Furthermore, this type of systems design allows for relatively quick modifications (i.e. reconfiguration of part of the system) to restore service delivery.

The 'preparedness and response' measure of a service may be thought of as the ability and time required to restore a service after receiving a direct impact and/or the immediate

\footnotetext{
${ }^{32}$ Notwithstanding the risk of spread of infectious disease from even one household deprived of sufficient safe water Hunter PR, Zmirou-Navier D, Hartemann P. "Estimating the impact on health of poor reliability of drinking water interventions in developing countries". Science of the Total Environment; 2009 2009, 2621 - 24; Bartram J, Hunter P. Bradley Classification of diseased transmission routes for water-related hazards. In: Bartram J, with Baum R, Coclanis PA, et al., eds. Routledge Handbook of Water and Health. London: Routledge, 2015.. This sort of 'impact' can be very long-term, even indefinite.

${ }^{33}$ PHR. Anatomy of a Crisis - A Map of Attacks on Health Care in Syria (Findings as of February 2016). Physicians for Human Rights: New York, 2016; Burnham GM, Lafta R, Doocy S. "Doctors leaving 12 tertiary hospitals in Iraq, 2004-2007". Social science \& medicine; 2009 (2) 2009, 172-7.

$34 \mathrm{REACH}$. Eatern Aleppo Household Assessment: Water Security. ACTED and IMPACT Initiatives, UN Operational Satellite Applications Programme: Geneva, August 2015 Profile, 2015.

${ }^{35}$ Isabel Robinson and Ellen Nohle, "Proportionality and precautions in attack: The reverberating effects of using explosive weapons in populated areas" in this issue of the Review.

${ }^{36}$ Bocchini P, Frangopol D, Ummenhofer T, et al. "Resilience and Sustainability of Civil Infrastructure: Toward a Unified Approach". Journa of Infrastructure Systems; 2014 (2) 2014.
} 
reverberating effects of an explosion. Especially if it occurs at the beginning of hostilities or in a situation of limited armed conflict, consumables lost to the violence (like chlorine stocks) may be replaced, and problems with damaged infrastructure can be worked around through temporary measures (such as water trucking), or soon repaired (e.g. a patch welded to a steel reservoir pierced by a single tank shell). The absence of a small number of staff in the shortterm can be handled relatively easily through replacement staff, such that the service keeps running.

The ability of local authorities or relief providers to respond to the direct or reverberating effects of explosive weapons is itself a question of both the scale of the damage, as well as the state of the service prior to the explosion. For example, the total destruction of a water reservoir obliges the temporary installation of a temporary water tank to maintain storage capacity, but this will be a fraction of the original capacity, at best. ${ }^{37}$ The partial destruction of a water booster pumping station is typically more difficult to work around, repair, or replace than a reservoir, meaning considerably more time is likely necessary to restore the service. Because the technologically-sophisticated equipment is not readily repairable on-site (or sometimes in-country), it is not uncommon that it must be shipped out for repair to special machine-shops or even to the original manufacturer, which is both expensive, and logistically difficult. ${ }^{38}$ This is particularly the case if the quality of local production is poor or the stocks have been depleted during the protracted conflict. In Iraq, for example, chlorine tablets were used instead of the chlorine gas that water treatment plants were designed to operate with, ${ }^{39}$ meaning there is no assurance that the water was treated to a safe level. The 'baseline' resilience of a service in protracted conflicts is constantly changing (improving after repairs, but generally degrading over time), and thus - for the purposes of this analysis $-\mathrm{a}$ factor that to the extent possible should be considered prior to an attack.

\section{[Head 2] Impact in space and over time}

By definition, the direct impact of explosive weapons on urban services is confined to the physical 'impact area' of the explosive being considered. The impact area varies considerably with the type of explosive weapon, but for each is defined as the distance over which the initial blast wave creates pressure, ${ }^{40}$ as well as the distance of any fragmentation delivered, and the dissipation of thermal energy. The blast wave dissipates within milliseconds, while the fragmentation and thermal energy dissipates typically within seconds. For example, explosive weapons with wide 'area effects' like the surface-to-surface Scud missile or an

37 'Downstream' reservoirs that supply small neighbourhoods have a capacity of about 500 cubic metres, for example, while those placed more 'upstream' to serve 250,000 people are up to 5,000 cubic metres (as the al Montar reservoir in Gaza). Most rapid-deployment tanks are limited to 95 cubic metres, though some can be 200 or 500 cubic metres.

38 Pinera J-F. Cities, Water and War: Looking at how water utilities and aid agencies collaborate in cities affected by armed conflicts. Loughborough: LAP LAMBERT Academic Publishing 2011.

39 CARE International. Watsan Project Report - September 1997. Internal communication of CARE International classified as ICRC file no 022.: 1997.

${ }^{40}$ FEMA. Reference Manual to Mitigate Potential Terrorist Attacks Against Buildings. US Department of Homeland Security / FEMA 426: Washington DC, Risk Management Series, 2003. 
Mk84 bomb can damage a water reservoir, warehouse for spare parts, and a water supply operator within its target area of hundreds of metres, simultaneously.

As shown in Table 2, the extent of the reverberating effects of explosive weapons on urban services changes in space and time with the pre-attack baseline resilience of the service. To recall - for a service that is quite resilient prior to an attack, the reverberating effects of explosive weapons are expected to be dampened because the redundancies can provide alternative supply options and/or routes, and the spare parts and people required to install them are still available. By contrast, the reverberating effects of explosive weapons on a service that is quite vulnerable - that is to say, one that is already 'on its knees' - can extend much further afield and forward in time.

Investigating the determinants of the impact of the reverberating effects of explosive weapons on urban services thus obliges tackling several sets of variables: the three components of each service; the interdependencies of services; direct effects; reverberating effects; and the up, mid, and downstream hierarchy. Table 2 clarifies the dynamics through a systematic summing of alternatives of the different sets of variables in different scenarios. The summary reveals the extent to which the baseline conditions and hierarchy influence the expected impact of the explosive weapons in space and time.

\begin{tabular}{|c|c|c|c|c|c|}
\hline \multicolumn{2}{|c|}{ Baseline Resilience } & Hierarchy & \multicolumn{3}{|c|}{ Reverberating Effects } \\
\hline Redundancies & $\begin{array}{l}\text { Preparedness/ } \\
\text { capacity to } \\
\text { Respond }\end{array}$ & $\begin{array}{l}\text { Hierarchy of } \\
\text { explosion } \\
\text { (in the service) }\end{array}$ & $\begin{array}{l}\text { Impression } \\
\text { in space } \\
\text { Confined or } \\
\text { Open }\end{array}$ & $\begin{array}{l}\text { Impression } \\
\text { in time } \\
1=\text { Immediate } \\
2=\text { Short-term } \\
3=\text { Mid-term } \\
4=\text { Long-term }\end{array}$ & $\begin{array}{l}\text { Magnitude } \\
\text { (relative } \\
\text { number of } \\
\text { people affected) } \\
\text { Low, Med, } \\
\text { High }\end{array}$ \\
\hline High & High & Downstream & Confined & 1 & $\mathrm{~L}$ \\
\hline High & High & Midstream & Confined & 2 & $\mathrm{M}$ \\
\hline High & High & Upstream & Open & 2 & $\mathbf{H}$ \\
\hline High & Med & Downstream & Confined & 3 & $\mathrm{~L}$ \\
\hline High & Med & Midstream & Confined & 3 & $\mathrm{M}$ \\
\hline High & Med & Upstream & Open & 3 & $\mathbf{H}$ \\
\hline High & Low & Downstream & Confined & 4 & $\mathrm{~L}$ \\
\hline High & Low & Midstream & Confined & 4 & $\mathrm{M}$ \\
\hline High & Low & Upstream & Open & 4 & $\mathbf{H}$ \\
\hline Medium & High & Downstream & Confined & 1 & $\mathrm{~L}$ \\
\hline Medium & High & Midstream & Confined & 1 & $\mathrm{M}$ \\
\hline Medium & High & Upstream & Open & 1 & $\mathbf{H}$ \\
\hline Medium & Low & Downstream & Confined & 3 & $\mathrm{~L}$ \\
\hline Medium & Low & Midstream & Confined & 3 & $\mathrm{M}$ \\
\hline Medium & Low & Upstream & Open & 3 & $\mathbf{H}$ \\
\hline Low & Low & Downstream & Confined & 4 & $\mathrm{~L}$ \\
\hline Low & Low & Midstream & Confined & 4 & M-H \\
\hline Low & Low & Upstream & Open & 4 & $\mathbf{H}$ \\
\hline
\end{tabular}


Table 2. Summary of the factors that determine the extent of the impact of explosive weapons in space and time, according to different scenarios of baseline resilience. The magnitude, delivery method and contact of the explosive is assumed constant in each scenario. Entries in bold are those with the highest magnitude.

A close reading of the table reveals a number of relevant dynamics. The first is that the greatest impact (i.e. those scenarios classed as 'open' in the space column, and graded ' 3 ' or ' 4 ' in the time column) occur where the explosive weapons is used on an 'upstream' part of a service that is low both in terms of quality and in capacity to respond. This confirms conventional thought on the subject, i.e. that the attacks which are the most likely to cause direct or reverberating effects over the largest area and for a prolonged period of time are those on the supply-end (i.e. upstream) infrastructure, especially if this is already degraded.

Second, the expected impact of explosive weapons across space is found to be shaped primarily by the hierarchy of the component within a service. That is, the spatial extent of the reverberating effects of explosive weapons on 'downstream' elements of an infrastructure system can be expected to be 'confined' (typically to a localized neighbourhood or even household level). The reverberating effects of explosive weapons on 'upstream' elements of a service are more open - limited only by the extent of the infrastructure of the network, which often spans dozens of kilometres and can serve upwards of hundreds of thousands of people.

Third, the expected impact of explosive weapons on urban services in time is found to be determined primarily by the baseline resilience of the service. That is, the reverberating effects upon any component of a service (whether people, hardware, or consumables; or located up, mid, or downstream) is likely to be shorter when the pre-attack quality of the service and its ability to respond is high. Reverberating effects of explosive weapons on the service are expected to last much longer when the baseline conditions of the service are poor. Generally, a service that is already vulnerable is more likely to be disrupted for a longer period than one that is robust, in other words (and can span from days to decades, and distinct from other reverberating effects (e.g. on public health, markets, etc), which might not be similarly bound). .

There is also considerable differentiation of the impact on time within each scenario. For services of the same baseline quality, for example, the magnitude of the reverberating effects varies directly with the ability to respond. Likewise, in situations of equal ability to respond, the magnitude of the reverberating effects varies directly with the quality of service.

\section{[Head 1] Implications for proportionality and precaution in attack}

The analysis has demonstrated how the impact of explosive weapons on any component of a service can be direct and reverberate within the same service or on other services. The duration and spatial extent of the direct and reverberating effects depend primarily on the extent of the damage to the functionality of a service component. The overall impact across space varies significantly, being determined primarily by the hierarchy of the component suffering the direct effect (damage on upstream components typically having the most 
widespread impact). The duration of the overall impact is determined mainly by the preexplosion operational resilience of the service, as measured in terms of system redundancies and emergency preparedness and response. More specifically, and in the majority of cases seen, the greatest impact of explosive weapons on urban services is a function of the extent of the damage to upstream or midstream infrastructure (i.e. that which produces or delivers the bulk of the service), the nature and extent of the reverberations downstream of the elements of any service component, the 'domino effect' onto others services, and of the time required to restore the service.

The findings hold a number of implications for the rules on proportionality and precaution in attack, as they shed light on what impact on urban services can be 'reasonably foreseeable'. As Robinson and Nohle discuss, the rules oblige attackers "to take into account the expected incidental loss of civilian life, injury to civilians or damage to civilian objects arising from a particular attack", which the ICRC interprets to include the foreseeable reverberating effects of an attack. ${ }^{41}$ The relevant question when carrying out a proportionality assessment for an attack on a military objective expected to cause damage to a service is: to what extent are the direct impact and reverberating effects 'reasonably foreseeable'?

The analysis has emphasised that service hardware is the chief component of concern of the use of explosive weapons, and that upstream and midstream infrastructure have primacy within that particular service component. A number of features of such primary service hardware should be considered. First, the detailed layout of the service system is often only known by the staff of the service provider that operates the service (typically at the municipal level), even if the original layout is sometimes recorded in as-built plans or standard operating procedures. Regardless of whether an attack is planned with the luxury of time or a result of dynamic targeting (i.e. time sensitive), access to this level of information is not likely to be readily available. However, in some circumstances with time and experience a greater level of information and knowledge will have been acquired (e.g. in protracted conflict, or during periods of prolonged occupation), and hence could be expected to inform any proportionality assessment ${ }^{42}$. Given the fact that 'collateral damage' is assessed, this analysis suggests that resource personnel can and should be used wherever possible to gain the knowledge of the basic layout and functioning of the service. In the absence of such information, the alternative is to rely on the expert opinion of engineers specialised in a particular urban service (i.e. water supply, wastewater collection and treatment, and power supply).

Second, it happens that most of this upstream and midstream infrastructure is identifiable, in that it is typically located at ground level and takes on familiar spatial or design patterns. For example, the clarifying tanks emblematic of water treatment plants are readily distinguishable for being circular and from about three to 15 metres in diameter. They are also quite distinct from conventional electrical power plants or conventional wastewater treatment plants. Secondary booster pumping stations and ground level and elevated water reservoirs are clearly distinguishable if not covered, and so also discernible to a trained eye.

\footnotetext{
${ }^{41}$ I. Robinson and E. Nohle, above note xxx.

${ }^{42}$ Which could include but is not limited to a collateral damage estimation.
} 
If such infrastructure is identifiable from the air (or from the ground when in the line-ofsight), it follows that a weapons controller could be trained to distinguish it from other parts of an urban landscape.

Third, there is considerable specialist knowledge of the direct effects of the use of explosive weapons on urban services, at least on infrastructure. This lies with militaries, ${ }^{43}$ local authorities, ${ }^{44}$ and some humanitarian organizations ${ }^{45}$. In terms of both physical protection of critical infrastructure and preparedness for a particular event, it is also documented in internal or open-source publications. ${ }^{46}$

Given these three characteristics, even without access to the as-built plans of critical infrastructure, much of the impact caused by the explosive weapon upon urban services is reasonably foreseeable. The statement holds whether the weapons have 'wide-area effects' or not. However, such reverberating effects are not yet as routinely catalogued (or perhaps even conceptualised) by belligerents, local authorities, and relief agencies. Amongst other implications that are to be addressed in separate analysis, ${ }^{47}$ then, the findings suggest that the process of carrying out a proportionality assessment that involves urban service infrastructure would benefit from: i) the direct and consistent engagement of specialised engineers within the targeting cell; and ii) greater familiarity of the weapons controller with services, infrastructure and systems in urban areas (and when possible in theatre). The latter will ensure a greater likelihood of identifying civilian objects (which are static), and associate them with the foreseeable reverberating effects (including those that are immediate and within systems).

The analysis holds two further implications for discussions about rules on proportionality and precaution in attack. It is worth returning to the articulation in footnote 17 of reverberating effects on urban services as a subset of the 'foreseeable reverberating effects of an attack' in the general sense, as described by Robinson and Nohle (this volume). The former are not only generally more bounded in space and over time as this analysis shows, they are also arguably even more easily foreseeable than the latter (which extend, according to the definitions employed here, beyond the reverberating effects on urban services themselves).

\footnotetext{
${ }^{43}$ US Army. Intelligence Support to Urban Operations. US Army Intelligence Center and School, for the US Training and Doctrine Command: Headquarters, Department of the Army, Field Manual FM 2-914, 2008. and Patterson 2000

44 e.g. the Southern Water Board, Lebanon (in 2006) and the Coastal Municipalities Water Utility (CMWU) in the Gaza Strip.

45 e.g. the ICRC

${ }^{46}$ Canada, Public Safety (2010). Risk Management Guide for Critical Infrastructure Sectors. Version 1.0. Ottawa. Public Safety Canada; CEPS (2010). Protecting Critical Infrastructure in the EU. CEPS Task Force Report. Brussels. Centre for European Policy Studies; FEMA (2003). Reference Manual to Mitigate Potential Terrorist Attacks Against Buildings. Risk Management Series. Washington DC. US Department of Homeland Security / FEMA 426.

47 Including the protection offered by International Humanitarian Law. Initial discussions are to be found in Tignino, Mara (2016). Water During and After Armed Conflicts: What Protection in International Law? , Brill; Gisel, Laurent (2015). The use of explosive weapons in densely populated areas and the prohibition of indiscriminate attacks. 37th Round Table on Current Issues of International Humanitarian Law, Sanremo 4-6 September 2014, International Institute of Humanitarian Law.
} 
Finally, the analysis further contributes to a related debate about the ability to mitigate the impact of explosive weapons on urban services (whether reasonably foreseeable or not). As the ICRC Urban Services report states, "(a)lthough the rules on the conduct of hostilities do not specifically state that an attacker must take account of the decreased capacity of essential services caused by previous attacks, to the extent that such decreased capacity is foreseeable, it must be taken into account". ${ }^{48}$ The analysis has shown that the ability of a system to respond to damage or disruption is one of the key elements of the baseline conditions that determine the extent of the reverberating effects, most notably over time.

\section{[Head 1] Acknowledgements}

The authors would like to thank Thomas de Saint Maurice, Ellen Nohle, Laurent Gisel, and Stephen Robinson for very helpful comments on earlier drafts, as well as Philippe Dross, Evaristo de Pinho Oliveira and Javier Cordoba for numerous discussions that have helped frame the arguments.

ICRC. Urban services during protracted armed conflict: a call for a better approach to assisting affected people. International Committee of the Red Cross: Greneva, 2015.

ICRC. Urban services during protracted armed conflict: a call for a better approach to assisting affected people. International Committee of the Red Cross: Geneva, 2015.

${ }^{48}(2015: 40)$ 